\title{
Tingkat Pengetahuan Kader tentang Deteksi Dini Risiko Tinggi Ibu Hamil dengan Perilaku Melapor pada Tenaga Kesehatan
}

\author{
Yuniasih Purwaningrum ${ }^{1}$ \\ Prodi Kebidanan Jember Jalan Srikoyo No. 106 Patrang Jember, Indonesia ${ }^{1}$ \\ Email: yunipurwaningrum268@gmail.com
}

\begin{abstract}
Pregnancy and childbirth are natural processes, but special self-care is needed so that the mother and fetus are in good health. Therefore a normal pregnancy has a risk, but does not directly increase the risk of maternal death. This situation is called a risk factor. In 2016, early detection of high risk of pregnant women by cadres in Bondowoso District reached $7.99 \%$ of the existing target of $10 \%$, while data obtained from Wringin Health Center with a cadre of 220 people and the number of pregnant women 625 over a period of 1 year achieved early detection high risk of pregnant women $2.3 \%$. The purpose of this study was to analyze the relationship between the level of knowledge of cadres about early detection of high risk pregnant women with reporting behavior to health workers in the work area of Wringin Health Center Bondowoso in 2017. The research design used was analytic correlation with cross sectional design, population 220 obtained subject 65 cadres, by using regional samples or probability sample areas. Instruments include questionnaires and writing sheets. The collected data is processed by Chi Square test. The results showed that the level of knowledge of cadres about early detection of high risk pregnancies with the criteria of both $48 \%$ and criteria was quite $52 \%$. Behavior reporting to health workers $75 \%$ reported all incidents and $25 \%$ reported partially. The statistical test with a significance level of 0.05 was obtained from the count X2 3,790,899. While X2 chi square table is 3.481 then ho is rejected and ha is accepted. There is a relationship between knowledge of cadres about early detection of high risk pregnant women and reporting behavior with the strength of the relationship 0.234749. The conclusion of the study is that cadre knowledge has a significant (low / weak but sure) effect on the behavior of cadres in reporting early detection of high risk of pregnant women. It needs to be maintained and increased again so that no high-risk pregnant women are undetected.
\end{abstract}

Keywords: cadres report, early detection of high risk pregnant women, knowledge

\section{Pendahuluan}

Kehamilan dan persalinan merupakan proses alami, tetapi perlu perawatan diri yang khusus agar ibu dan janin dalam keadaan sehat. Karena itu kehamilan yang normalpun mempunyai resiko kehamilan, namun tidak secara langsung meningkatkan resiko kematian ibu. Keadaan tersebut dinamakan faktor resiko (Kemenkes, 2014).

Menurut Survei Demografi dan Kesehatan Indonesia (SDKI) pada tahun 2015 Angka Kematian Ibu (AKI) Indonesia sebesar 305 per 100.000 kelahiran hidup. Sebagian besar penyebab kematian ibu secara langsung adalah komplikasi yang terjadi pada saat persalinan dan segera setelah bersalin. Penyebab tersebut dikenal dengan trias klasik yaitu perdarahan (28\%), eklampsia (24\%) dan infeksi (11\%). Sedangkan penyebab tidak langsung antara lain adalah ibu hamil menderita Kurang Energi Kronis (KEK) 37
$\%$, anemia (Hb kurang dari 11 gr \%) $40 \%$ (Kemenkes, 2015).

Data yang diperoleh di Dinas Kesehatan Bondowoso Tahun 2016, deteksi dini resiko tinggi ibu hamil oleh kader mencapai 7,99\% dari target yang ada $10 \%$.

Sedangkan data yang diperoleh dari Puskesmas Wringin dengan jumlah kader 220 orang dan jumlah ibu hamil selama kurun waktu 1 tahun (2016) sebanyak 625 orang, pencapaian deteksi dini resiko tinggi ibu hamil 2,3\% dari target yang ada $10 \%$. Menurut WHO seseorang akan melakukan sesuatu dipengaruhi oleh faktor : pengetahuan, sikap, orang penting sebagai referensi, sumber daya dan kebudayaan (Notoatmodjo, 2003).

Dari permasalahan tersebut, tujuan penelitian ini untuk mengetahui hubungan tingkat pengetahuan kader tentang deteksi dini resiko tinggi $\mathrm{ibu}$ hamil dengan perilaku melapor pada tenaga kesehatan diwilayah 
kerja Puskesmas Wringin Kabupaten Bondowoso.

\section{Metode}

Desain penelitian ini adalah analitik korelasi dengan pendekatan cross sectional dengan mempelajari dinamika korelasi antara faktor - faktor resiko dengan efek pengumpulan data sekaligus pada suatu saat.

\subsection{Metode Pengumpulan Data}

Populasi pada penelitian ini adalah kader sebanyak 220 orang yang ada di wilayah kerja Puskesmas Wringin. Subjek diambil dengan menggunakan sampel wilayah atau area probability sample yaitu teknik sampling yang dilakukan dengan mengambil wakil dari setiap wilayah yang terdapat dalam populasi. Berdasarkan rumus diperoleh subjek sebanyak 65 kader.

Instrumen yang dipergunakan untuk mengukur variabel tingkat pengetahuan adalah kuisioner dengan kategori baik, cukup, kurang. Variabel perilaku melapor pada tenaga kesehatan diukur dengan menggunakan lembar tulis dengan kategori melapor, sebagian melapor, tidak melapor. Data yang berhasil dikumpulkan diolah dengan uji statistik Chi Square.

\subsection{Metode Analisis Data}

Uji Chi Square Untuk mencari hubungan antara 2 variabel atau lebih dilakukan dengan menghitung korelasi antara variabel yang dicari dimana kuatnya hubungan antara variabel yang dinyatakan dalam koefisiensi kontingensi (Sugiyono, 2007).

\section{Hasil dan Pembahasan}

Berikut hasil penelitian yang meliputi karakteristik usia, pendidikan, jenis pekerjaan, tingkat pengetahuan, perilaku melapor, dan hubungan pengetahuan dengan perilaku melapor subjek penelitian.

\section{a. Karakteristik Berdasarkan Usia Subjek}

Karakteristik subjek berdasarkan usia ditunjukkan pada tabel 1 dibawah ini.
Tabel 1. Distribusi frekuensi usia kader di wilayah kerja Puskesmas Wringin Kabupaten Bondowoso 2017

\begin{tabular}{cccc}
\hline No & Usia (th) & Jumlah & $\begin{array}{c}\text { Persentase } \\
\text { (\%) }\end{array}$ \\
\hline 1 & $19-21$ & 5 & 8 \\
2 & $22-24$ & 16 & 25 \\
3 & $25-27$ & 14 & 22 \\
4 & $28-30$ & 12 & 18 \\
5 & $31-33$ & 8 & 12 \\
6 & $34-36$ & 6 & 9 \\
7 & $37-39$ & 4 & 6 \\
& Total & 65 & 100 \\
\hline
\end{tabular}

Dari tabel 1 dapat dilihat subjek terbanyak pada katerori usia berusia 22 - 24 tahun sebanyak 16 orang (25\%), dan paling sedikit pada kategori umur 37 - 39 tahun sebanyak $(6 \%)$.

\section{b. Tingkat pendidikan subjek}

Karakteristik subjek berdasarkan tingkat pendidikan ditunjukkan pada tabel 2 dibawah ini.

Tabel 2. Distribusi frekuensi pendidikan kader di wilayah kerja Puskesmas Wringin Kabupaten Bondowoso 2017

\begin{tabular}{clcc}
\hline No & $\begin{array}{c}\text { Jenjang } \\
\text { pendidikan }\end{array}$ & Jumlah & $\begin{array}{c}\text { Persentase } \\
(\mathbf{\%})\end{array}$ \\
\hline 1 & SD & 35 & 54 \\
2 & SMP & 18 & 28 \\
3 & SMA & 9 & 14 \\
4 & Perguruan & 3 & 4 \\
& tinggi & & \\
& Total & 65 & 100 \\
\hline
\end{tabular}

Dari tabel 2 diketahui sebagian besar responden ( $54 \%$ ) berpendidikan $\mathrm{SD}$, dan sisanya pada tingkat pendidikan SMP, SMA, dan perguruan tinggi.

\section{c. Jenis pekerjaan subjek}

Karakteristik tingkat pekerjaan subjek berdasarkan ditunjukkan pada tabel 3 dibawah. 
Tabel 3. Distribusi frekuensi pekerjaan kader di wilayah kerja Puskesmas Wringin Kabupaten Bondowoso 2017

\begin{tabular}{llcc}
\hline No & \multicolumn{1}{c}{$\begin{array}{c}\text { Jenis } \\
\text { pekerjaan }\end{array}$} & Jumlah & $\begin{array}{c}\text { Persentase } \\
(\%)\end{array}$ \\
\hline 1 & $\begin{array}{l}\text { Mengurus } \\
\text { rumah tangga }\end{array}$ & 38 & 58 \\
2 & Tani & 24 & 37 \\
3 & Dagang & 3 & 5 \\
& Total & 65 & 100 \\
\hline
\end{tabular}

Dari tabel 3 dapat diketahui sebagian besar subjek (58\%) mengurus rumah tangga dan sisanya bertani dan berdagang.

\section{d. Tingkat pengetahuan subjek}

Karakteristik subjek berdasar tingkat pengetahuan ditunjukkan pada tabel 4 dibawah ini.

Tabel 4. Distribusi frekuensi pengetahuan kader tentang deteksi dini resiko tinggi ibu hamil di wilayah kerja Puskesmas Wringin Kabupaten Bondowoso 2017.

\begin{tabular}{clcc}
\hline No & $\begin{array}{c}\text { Tingkat } \\
\text { pengetahuan }\end{array}$ & Jumlah & $\begin{array}{c}\text { Persentase } \\
(\%)\end{array}$ \\
\hline 1 & Baik & 31 & 48 \\
2 & Cukup & 34 & 52 \\
3 & Kurang & 0 & 0 \\
& Total & 65 & 100 \\
\hline
\end{tabular}

Dari tabel 4 dapat diketahui subjek yang berpengetahuan cukup sebanyak 52\%, dan sisanya berpengetahuan baik (48\%). Tidak ada subjek yang berpengetahuan kurang.

\section{e. Perilaku pelaksanaan melapor}

Karakteristik subjek berdasar perilaku melapor ditunjukkan pada tabel 5 dibawah ini.

Tabel 5. Distribusi frekuensi perilaku pelaksanaan melapor tentang deteksi dini resiko tinggi ibu hamil pada tenaga kesehatan di wilayah kerja Puskesmas Wringin Kabupaten Bondowoso 2017

\begin{tabular}{clcc}
\hline No & $\begin{array}{l}\text { Perilaku } \\
\text { melapor }\end{array}$ & Jumlah & $\begin{array}{c}\text { Persentase } \\
(\%)\end{array}$ \\
\hline 1 & Melapor & 49 & 75 \\
2 & $\begin{array}{l}\text { Sebagian } \\
\text { melapor }\end{array}$ & 16 & 25 \\
\hline
\end{tabular}

\begin{tabular}{rlcc}
\hline 3 & $\begin{array}{l}\text { Tidak } \\
\text { melapor } \\
\text { Total }\end{array}$ & 0 & 0 \\
& 65 & 100 \\
\hline
\end{tabular}

Dari tabel 5 dapat diketahui bahwa sebagian besar subjek berperilaku baik melaporkan semua kejadian (75\%), dan sisanya berperilaku cukup yaitu melaporkan sebagian kejadian. Tidak ada subjek yang yang berperilaku tidak melaporkan kejadian.

\section{f. Hubungan tingkat pengetahuan dan perilaku melapor}

Data variabel tingkat pengetahuan dan perilaku melapor dimasukkan kedalam tabel koefisien kontigensi sebagaimana ditunjukkan pada tabel 6 dibawah ini.

Tabel 6. Hubungan tingkat pengetahuan kader tentang deteksi dini resiko tinggi ibu hamil dan perilaku kader dalam melaporkan deteksi dini resiko tinggi ibu hamil pada tenaga kesehatan di wilayah kerja Puskesmas Wringin Kabupaten Bondowoso 2017

\begin{tabular}{llcccc}
\hline & $\begin{array}{l}\text { Penget } \\
\text { ahuan } \\
\text { No }\end{array}$ & \multicolumn{3}{c}{ Perilaku kader } & \\
\cline { 3 - 5 } & subjek & $\begin{array}{c}\text { Mela } \\
\text { Por }\end{array}$ & $\begin{array}{c}\text { Seba } \\
\text { gian } \\
\text { mela } \\
\text { por }\end{array}$ & $\begin{array}{c}\text { Tidak } \\
\text { Mela } \\
\text { por }\end{array}$ & Total \\
\hline 1 & Baik & 20 & 11 & 0 & 31 \\
2 & Cukup & 29 & 5 & 0 & 34 \\
3 & Kurang & 0 & 0 & 0 & 0 \\
& Total & 49 & 16 & 0 & 65 \\
& & & & & \\
\hline
\end{tabular}

Nilai kekuatan hubungan berdasarkan hasil penghitungan didapatkan hasil 0,23 yang artinya Ha diterima ada hubungan pengetahuan kader tentang deteksi dini resiko tinggi ibu hamil terhadap perilaku melaporkan deteksi dini resiko tinggi ibu hamil dengan kekuatan hubungan $0,20<\mathrm{kk}<0,40=$ rendah/lemah tapi pasti.

\section{Hasil dan Pembahasan}

a. Gambaran tingkat pengetahuan kader tentang deteksi dini resiko tinggi ibu hamil di Wilayah Kerja Puskesmas Wringin Kabupaten Bondowoso.

Berdasarkan tabel 4. jumlah ibu yang tingkat pengetahuannya baik sebanyak 31 
kader (48\%) dan jumlah ibu dengan tingkat pengetahuan cukup sebanyak 34 (52\%).

Menurut Bloom yang dikutip dari Latipun 2002, bahwa pengetahuan dipengaruhi oleh usia dimana tingkat kemampuan dan kematangan seseorang akan lebih matang dalam berfikir dan menerima informasi, sedangkan pendidikan dapat mempengaruhi seseorang termasuk juga perilaku seseorang terutama dalam memotivasi untuk berperan dalam pembangunan keseluruhan. Maka selaras dengan itu dari hasil kuesioner tampak bahwa jenjang pendidikan kader di Wikayah Kerja Puskesmas Wringin adalah tingkat dasar (SD). Namun demikian walaupun mayoritas pendidikannya SD, tingkat pengetahuannya tentang deteksi dini resiko tinggi ibu hamil relatif tinggi yaitu 34 kader (52\%). Untuk itu tingkat pengetahuan kader tentang deteksi dini resiko tinggi ibu hamil perlu dipertahankan dan ditingkatkan lagi melalui penyuluhan, pelatihan-pelatihan yang diadakan oleh tenaga kesehatan sehingga pengetahuan kader akan meningkat dan tidak ada lagi ibu hamil yang tidak dideteksi.

b. Gambaran perilaku kader dalam melaporkan deteksi dini resiko tinggi ibu hamil pada tenaga kesehatan di Wilayah Kerja Puskesmas Wringin Kabupaten Bondowoso

Berdasarkan tabel 5. dijelaskan bahwa kader yang berperilaku melaporkan semua kejadian 49 kader (75\%) dan jumlah kader yang berperilaku melaporkan sebagian kejadian 16 kader (25\%). Menurut Notoatmodjo (2003) bahwa perilaku manusia terbentuk atas dasar adanya pengetahuan terlebih dahulu. Penelitian ini membuktikan bahwa perilaku dengan didasari pengetahuan lebih langgeng dari pada perilaku tanpa adanya pengetahuan. Dari sini masih terlihat belum semua kader di Wilayah Kerja Puskesmas Wringin melaporkan deteksi dini resiko tinggi ibu hamil pada tenaga kesehatan yang dikarenakan masih ada desa yang tidak bisa di jangkau (45 \%) wilayah kerja Puskesmas Wringin adalah pegunungan.

c. Hubungan tingkat pengetahuan dengan perilaku melaporkan deteksi dini resiko tinggi ibu hamil pada tenaga kesehatan

Tabel 6. menjelaskan bahwa pengetahuan kader berpengaruh secara siqnifikan (rendah/lemah tapi pasti) terhadap perilaku kader dalam melaporkan deteksi dini resiko tinggi ibu hamil.

\section{Simpulan dan Saran \\ 4.1 Simpulan}

Pengetahuan kader berpengaruh secara signifikan (rendah/lemah tapi pasti) terhadap perilaku kader dalam melaporkan deteksi dini resiko tinggi ibu hamil di Wilayah Kerja Puskesmas Wringin Kabupaten Bondowoso.

\subsection{Saran}

Sebagai bahan masukan bagi tempat pelayanan kesehatan guna meningkatkan cakupan deteksi dini resiko tinggi kehamilan oleh masyarakat.

\section{Daftar Pustaka}

Data Dinas Kesehatan Kabupaten Bondowoso Tahun 2016.

Data Puskesmas Sumberwringin Tahun 2016.

Kementrian Kesehatan RI (2014), Pedoman Pemantauan Wilayah Setempat Kesehatan Ibu dan Anak, Jakarta.

Kementerian Kesehatan RI (2015) Infodatin, Jakarta.

Notoatmodjo S (2002), Metodologi Penelitian Kesehatan, Jakarta, Renika Cipta.

Notoatmodjo S (2003), Pendidikan dan Perilaku Kesehatan, Jakarta, Renika Cipta. 
ISSN : 2354-5852

e-ISSN : 2579-5783

Sugiyono (2007), Statistik Non Parametris

Untuk Penelitian, Bandung, CV.

Alfabeta 